\title{
BAHASA DEMOKRATIS DI DALAM MEDIA TELEVISI INDONESIA
}

\author{
Riyadi Santosa, Agus Dwi Priyanto, Ardianna Nuraeni
}

\begin{tabular}{c} 
Email: riyadisantosa1960@gmail.com \\
Fakultas Sastra dan Seni Rupa (FSSR) Universitas Sebelas Maret (UNS) Surakarta \\
Alamat Koresponden: Jalan Ir. Sutami 36A Surakarta \\
\hline
\end{tabular}

\begin{abstract}
This research attempts to depicts the language used in Indonesian television, especially in news, editorial, and talk show in post reform era. The main issue in this research is the language used in Indonesian television contributes to the formation of democracy in this country. To answer the question, this research applies Systemic Functional Linguistics (SFL) that is able to portray the social processes and the language that is representation of the social processes, including their genres and registers. The results show that news exploits recount whereas editorial and talk show employ discussion genre. The recount and discussion genres in news and editorial and talk show accelerate the atmosphere of democratization in Indonesia. News provides facts and phenomena whereas editorial and talk show discusses them. However, in the level of register, editorial and talk show exploit the use of more raised evaluation that a number of communication experts believe that Indonesian editorial and talk show go beyond the democracy level or are still provocative.
\end{abstract}

\section{Keywords}

Bahasa Demokratis, Genre, Register, Appraisal

\section{Pendahuluan}

Setelah era reformasi masyarakat pada umumnya masih mencari-cari bentuk demokrasi yang dapat diterima semua pihak. Masyarakat sering menginterpretasikan demokrasi sebagai kebebasan secara mutlak. Kebabasan mutlak memang tidak pernah muncul di dalam definisi demokrasi dimana pun. Akan tetapi perilaku verbal dan tindakan fisik masyarakat menampakan kebebasan mutlak tanpa batas tersebut. Walaupun hal ini tampak berkurang pada akhir-akhir ini, tetapi gejala tersebut masih hadir secara signifikan di tengah-tengah masyrakat Indonesia. Hal ini juga terjadi di dunia media masa kita. Sering kali media masa kita membuat pemberitaan, editorial, atau talk show dengan menggunakan bahasa provokatif. Bahasa provokatif demikian itu tampaknya mereka anggap sebagai representasi nilai-nilai demokratis yang sedang kita cari bersama. Akan tetapi, tidak disadari, sering kali bahasa provokatif tersebut tidak disengaja memprovokasi masyarakat. Penggunaan bahasa provokasi di media masa menjadi sangat signifikan karena pengaruhnya sangar besar terhadap masyarakat. Seringkali otoritas media masa tidak menyadari bahwa bahasa provokatif yang digunakan meresahkan masyarakat sehingga banyak media masa yang diperingatkan bahkan dibredel karena bahasanya yang tidak demokratis.

Bahasa provokatif, bahasa yang terlalu banyak menggunakan penilaian negatif yang melampaui batas-batas nilai demokratis, di media masa Indonesia termasuk bagian yang selalu menjadi fokus perhatian oleh pemerintah, terutama, Departemen Informasi dan Komunikasi. Hal ini dikarenakan menyangkut ketahanan dan pertahanan nasional. Pengamatan pada beberapa berita, editorial dan talk show pada beberapa program televisi dan media masa lainnya masih mengandung bahasa yang provokatif dan tidak demokratis. Jika hal ini tidak bisa diterima oleh masyarakat yang terlibat dengan masalah yang diberitakan, tentu saja, pemberitaan tersebut akan menimbulkan iritasi dan bisa jadi akan menimbulkan keresahan bahkan kericuhan sosial. 


\section{Penutup}

Tentang bentuk genre berita, editorial, dan talk show televisi, seperti yang dibahas di dalam pembahasan, genre berita televisi menggunakan genre rekon dengan struktur generik: orientasi dan urutan kejadian. Genre ini sudah sesuai dengan berita, karena fungsi berita memang menceriterakan kembali kejadian pada waktu lampau. Secara umum, di dalam temuan tersebut genre rekon ini didukung dengan hubungan konjungsi eksternal waktu baik melalui konjungsi, kontinuatif maupun metafor. Menurut para ahli komunikasi genre rekon ini sudah tepat digunakan karena genre rekon ini mewadahi fungsi berita sebagai pemberi informasi mengenai kejadian yang sudah silam.

Sementara itu, untuk editorial dan talk show yang umumnya berupa debat current affairs atau interview panel (Haarman dalam Tolson, 2001), menggunakan genre diskusi. Struktur generik diskusi terdiri dari isu, argumen pro dan kontra atau argumen dari berbabagai sisi, dan diakhiri dengan kesimpulan dan saran. Genre diskusi ini sudah sesuai dengan tujuan editorial dan talk show tersebut. Hal ini disebabkan genre diskusi ini memberikan kesempatan para nara sumber di dalam editorial dan talk show ini leluasa untuk berbeda pendapat dan melihat permasalahan dari sisi lain untuk memperoleh kesimpulan dan rekomendasiyang lebih holistik. Maka para ahli komunikasi juga menyetujui penggunakan genre diskusi ini pada program editorial dan talk show di media televisi Indonesia.

Register berita dan talk show dan editorial pada televisi dapat di ringkas berikut ini. Hubungan konjungtif yang membentuk berita intinya adalah hubungan konjungtif waktu eksternal baik yang berupa konjungsi, kontinuatif maupun metaphor. Hubungan konjungtif tersebut digunakan untuk menambah, membandingkan, mengurutkan, dan menjelaskan kejadian dan kualitas. Sementara pada editorial dan talkshow hubungan konjungtif intinya adalah hubungan konjungtif internal penambahan, perbandingan, waktu dan konsekuensi untuk menambah, membandingkan, mengurutkan membalas argument dan bukti serta menarik kesimpulan.

Kemudian sistem appraisal pada berita masih banyak menggunakan kata-kata deskriptif. Ada atitud tetapi masih dalam kategori wajar, tidak berlebihan dan tidak kontradiktif positif dan negatif. Sebaliknya, pada editorial dan talk show sistem appraisalnya didominasi atitud dengan sistem yang bertentangan positif dan negatif masing-masing dengan graduasi tinggi walaupun sama-sama bersumber heterogloss. Pada sistem intonasinya pada berita terdapat intonasi yang wajar dan normal tanpa adanya tekanan pada kata maupun frasanya. Akan tetapi pada editorial dan talk show terdapat intonasi yang naik dan penekanan kata-kata tertentu untuk strategi komunikasi untuk memperoleh atensi dan power. Akhirnya di dalam berita tidak ada rebutan ngomong sementara di dalam talk show terdapat rebutan 'turn-taking' untuk memperoleh kesempatan yang juga berarti power.

Tentang model genre dan register berita televisi yang demokratis, genre berita televisi yang sudah sesuai dengan tujuannya ialah rekon. Dengan genre rekon, berita televisi ini sudah dapat berfungsi untuk memberikan informasi mengenai kejadiankejadian waktu lampau di sekitar kita. Sekaligus, dengan genre ini berita televisi juga dapat memberikan entertaintment atau hiburan tersendiri kepada audiensnya. Sementara itu, untuk registernya, berita televisi ini sebagian besar juga sudah sesuai dengan tujuannya. Pertama, berita televisi ini sudah menggunakan tehnik recounting events dan refering resources as events. Dengan tehnik merekon kejadian pembawa berita menceriterakan urutan kejadian secara keseluruhan. Sementara itu, dengan tehnik merujuk sumber sebagai kejadian pembaca berita dapat membawa bukti berupa informan ke dalam berita mereka untuk membuktikan autentisitas berita mereka (Santosa, 2007).

Penggunaan hubungan konjungtif bersifat hubungan konjungtif waktu eksternal. Dengan hubungan konjungtif eksternal waktu ini penulis berita atau informan dapat menggunakan konjungsi, kontinuatif, atau metafor. Kemudian sistem appraisal yang musti dianut untuk berita ialah sistem atitud netral (tidak kelihatan positif atau negatif) dengan graduation (force atau focus) rendah atau lower untuk mengurangi subjektifitas berita. Di samping itu, berita harus menggunakan engagement atau sumber yang bersifat heterogloss atau dengan berbagai sumber agar berita lebih berimbang. Appraisal yang bertendensi dapat dilakukan asal dikover dengan informan yang jelas atau dengan menggunakan sistem merujuk sumber sebagai kejadian. Akhirnya, sistem fonologinya harus menggunakan intonasi yang menurun di akhir kalimat dan tidak perlu dengan penekanan kata atau frasa yang tendensius yang mengakibatkan berita menjadi tendensius.

Tentang model genre dan register editorial dan talk show televisi yang demokratis, Genre yang tepat untuk editorial dan talk show televisi ialah genre diskusi. Dengan genre diskusi ini editorial atau talkshow dapat mengeksploitasi isu sentral dengan argumen pro dan kontra atau argumen dari berbagai sisi dan diakhiri dengan kesimpulan dan 
rekomendasi. Dengan genre ini pulalah para programer talk show dan editorial dapat mengundang tokoh-tokoh dari berbagai kalangan yang diperlukan untuk membahas suatu isu, termasuk mengundang tokoh-tokoh yang kontroversial ke dalam acara atau genre ini. Hal ini disetujui oleh para tokoh komunikasi dan termasuk perancang program televisi (termasuk di dalamnya adalah tokoh pertelevisian Karni Ilyas) ini. Mereka tidak mempermasalahkan genre ini karena menurut mereka genre ini sudah sesuai dengan tujuan acara atau esensi genre editorial dan talkshow.

Akan tetapi di tingkat register masih terdapat ketidaksetujuan baik oleh para ahli komunikasi maupun programer atau editor tentang penggunaan sistem appraisal fonologis dan giliran bicara. Pertama pada sistem appraisal-nya, mestinya tidak perlu ada sistem atitud yang menilai orang atau sesuatu yang bersifat menghakimi, mengkritik yang berlebihan sehingga terasa memfitnah. Sistem atitudnya mestinya wajar tidak tendensius. Sampai saat ini sistem atitud bahasa televisi masih didominasi sistem atitud negatif dengan graduation yang tinggi. Hal ini dapat dibuktikan dengan adanya surat, sms atau tilpun yang merasa tersinggung sehingga protes pada televisi (Wawancara dengan Karni Ilyas). Para ahli komunikasi di Solo juga mengatakan bahwa atitud negatif yang tinggi juga merusak demokrasi di dalam dunia televise di Indonesia (wawancara dengan tiga pakar komunikasi dari FISIP UNS).
Kemudian mestinya pula para nara sumber yang terlibat di dalamnya termasuk juga host-nya menggunakan intonasi tekanan suara yang netral supaya tidak terdengar tendensius dan tidak netral. Para nara sumber tentu saja dapat membela karena memang tugasnya seperti itu. Akan tetapi intonasi dan tekanan kata yang berlebihan dapat merusak citra mereka sendiri yang menjadi terkesan berlebihan, vulgar dan emosional.

Yang terakhir, berebut giliran di dalam talk show atau editorial ini juga akan menimbulkan kesan tidak edukatif dan emosional, karena pada hahekatnya para nara sumber akan mendapatkan giliran yang sama. Jadi, tidak perlu berebut. Kesan tidak atau kurang demokratis akan terlihat jika para nara sumber berebut giliran untuk mendapatkan porsi yang lebih banyak. Pada hakekatnya demokrasi itu ialah mempunyai hak atau kesempatan berbicara tetapi juga wajib mendengarkan orang lain.

Berdasarkan prosedur dan hasil penelitian di atas penulis mempunyai saran sebagai berikut. Penelitian ini perlu ditindaklanjuti dengan penelitian dengan tema yang berlawanan yaitu: Bahasa otoriter dan Bahasa anarkis di televisi, untuk memperoleh gambaran yang sebaliknya. Penelitian ini juga perlu ditindaklajuti dengan penelitian pengembangan model dengan menguji cobakan model bahasa demokratis yang nonotorier dan non-anarkis di masyarakat, sehingga kita akan memperoleh model yang tepat untuk masyarakat kita.

\section{DAFTAR PUSTAKA}

Atmadi, T. 1985. Sistem Pers Indonesia: Catatan dan Teks Kuliah (Indonesian Press System: Lecture notes and texts). Jakarta: Gunung Agung.

Bhatia, V. K. 2004. Worlds of Written Discourse: A genre-Based View.London: Continuum.

Chambers, J. K., \& Trudgill, P. 1980. Dialectology. Cambridge: Cambridge University Press.

Chen, J. 2008. An Investigation into The Preference For Discourse Patterns In The Chinese Efl Learning Context. International Journal of Applied Linguistics (pp. 188-210): Blackwell.

Cook-Gumperz, J. 1986. Introduction: The Social Construction of Literacy. In J. Cook-Gumperz (Ed.), The social construction of literacy.Cambridge: Cambridge University Press.

Devitt, A. J., Bawarshi, A., \& Reiff, M. J. 2003. Materiality and Genre in The Study of Discourse Community. English College, 65(5), 541-558.

Duszak, A. 1998. Academic Writing in English and Polish: Comparing and Subverting Genres. International Journal of Applied Linguistics (pp. 191-212): Blackwell. 
Georgakopoulou, A., \& Goutsos, D. 2004. Discourse Analysis: An Introduction (2nd ed.). Edinburgh: Edinburgh University Press.

Graham, P. 2004. Predication, propagation, and mediation: Sfl, cda, and the inculcation of evaluative-meaning system. In L. Yound \& C. Harrison (Eds.), Systemic functional linguistics and critical discourse analysis: Studies in social change. London: Continuum.

Gray, B. 1986. Creating a Context for The Negotiation of Written Text. Paper presented at the The 12th Australian Reading Conference, Perth.

Halliday, M and Hasan, R. 1976. Cohesion in English. London: Longman.

1985. Language, Context and Text: Aspects of Language in A Social Semiotic Persperctive. Victoria: Deaking University.

Halliday, M. 1985a. Introduction to Functional Grammar. London: Edward Arnold. 1985b. Spoken and Written Language. Victoria: Deakin University Press. 1994. An Introduction to Functional Grammar. London: Edward Arnold.

Hodge, R. dan Kress, G. 1995. Social Semiotics. Cambridge: Polity Press.

Hyland, K. 2004. Genre and Second Language Writing.Michigan: The University of Michigan Press: Ann Arbor.

Hymes, D. H. 1977. Qualitative/Quantitative Research Methodologies in Education: A linguistic Perspective. Anthropology and Education Quarterly (pp. 165-176): Blackwell.

Hyon, S. 1996. Genre in Three Traditions: Implication for ESL. TESOL Quarterly (pp. 693-722): Teachers of English to Speakers of Other Languages.

Ihlstrom, C. 2004. The evolution of a new(s) genre. Gothenburg Studies in Informatics.

Kurzon, D. 1997. Legal Language: Varieties, Genres, Register, Discourse. International Journal of Applied Linguistics (pp. 119138): Blackwell.

Lacey, N. 2000. Narrative and Genre: Key Concepts in Media Studies. London: Macmilland Press Ltd.

Lincoln, Y. S., \& Guba, E. G. 1985. Naturalistic inquiry. Beverly Hills: Sage Publication.

Mann, W. C., \& Thomson, S. A. 1988. Rhetorical Structure Theory. Text, 8 (3), 243-281.

Martin, J. R. 1987. Factual Writing: Exploring and Challenging Social Reality.Victoria: Deakin University. 1992. English Text: System and Structure. Philadelpia: John Benjamins Publishing Company.

2006. Working with Discourse: The Sydney School. Paper presented at the Seminar and Workshop on Systemic Functional Linguistics, Jakarta.

Martin, J. R. and Rose, D. 2003. Working With discourse: Meaning Beyond The Clause. London: Continuum.

Matthiessen, C. M. I. M. 1992. Grammatical cartography.Sydney: University of Sydney.

Moessner, L. 2001. Genre, Text Type, Style, Register: A Terminological Maze? European Journal of English Studies (pp. 131-138): Routledge.

Nunan, D. 2008. Exploring Genre and Register in Contemporary English. English Today 94: Cambridge University Press.

Patton, M.Q. 1984. Qualitative Evaluation Methods. Beverhy Hills: Sage Publication.

Power, R. 2000. Mapping Rhetorical Structures to Text Structures by Constraint Satisfaction. Brighton: ITRI, University of Brighton. 
Ramsay, G. 2000. Linearity In Rhetorical Organisation: A Comparative Cross-Cultural Analysis of News Text From People's Republic of China and Australia. International Journal of Applied Linguistics (pp. 241257): Blackwell.

Rastier, F. 1997. Meaning and Textuality. Toronto: University of Toronto Press.

Reid, Ian (ed). 1989. The Place of Genre in Learning: Current Debate. Victoria: Deakin University.

Santosa, R. 2007. English for Journalism. Draf Buku, FSSR,UNS

2010 Logika Wacana: Analisis Hubungan Konjungtif Berdasarkan Linguistik Sistemik Fungsional. Surakarta: UNS Press.

2010 Posisi Semiotik Genre Mikro dan Makro. Unpublished Research. Graduate Program, UNS, Surakarta.

2003. Semiotika Sosial Pandangan terhadap Bahasa. Surabaya: Pustaka Eureka.

et.al. 2007. Sastra Anak sebagai Wahana Pengenalan dan Pengasuhan Ideologi: Sebuah Kajian Wacana. Dikti: Penelitian Fundamental 2 tahun dari 2006-2007.

Skulstad, A. S. 2005. The Use of Metadiscourse in Introductory Sections of A New Genre. International Journal of Applied Linguistics, 15(1).

Spradely, J. P. 1980. Participant observation. New York: Holt, Rinehart and Winston.

. 2006. Metode Etnografi (Ethnographic Methods). (M. Z. Elizabeth, Trans.). Yogyakarta: Tiara Wacana.

Strauss, A., \& Corbin, J. 2003. Dasar-dasar penelitian kualitatif: Tatalangkah dan tehnik-tehnik teoritisasi data (Basis of qualitative research: Grounded research procedures and techniques) (M. Shodiq \& I. Muttaqien, Trans.). Yogyakarta: Pustaka Pelajar.

Stuart-Smith, V. 2007. The hierarchical organization of text as conceptualized by rhetorical structure theory: A systemic functional perspective, Australian Journal of Linguistics (pp. 41-61): Routledge.

Sutopo, H.B. 2002. Metodologi Penelitian Kualitatif: Dasar Teori dan Terapannya dalam Penelitian. Surakarta: Sebelas Maret University Press.

Swales, J. 1990. Genre Analysis. Oxford: Oxford University Press.

Thomson, G. 2004. Introducing Functional Grammar (Second ed.). London: Arnold.

Tolson, Andrew. 2001. Introduction: The Talk Showphenomenon, in Tolson (Ed) Television talk show: Discourse, Performance, Spectacle. London: Lawrence Erlbaum Associate, Publishers

Widdowson, H. G. 2007. Discourse analysis. Oxford: Oxford University Press.

Yin, R. K. 2002. Studi Kasus: Desain dan Metode (Case study: Design and Methods) (M. D. Mudzakir, Trans.). Jakarta: RajaGrafndo Persada.

Yoshioka, T., \& Herman, G. 2000. Coordinating Information Using Genres. Cambridge, MA: MIT: Sloan School of Managmenet: Center for Coordination Science.

Wawancara dengan 1) Prof. Dr. Totok Sarsito, SU, MA Dosen FISIP UNS, 2) Prof. Drs. Pawito, MA, Ph.D. Dosen FISP UNS, 3) Dr. Widodo Muktiyo, MS, Dosen FISIP UNS, 4) Karni Ilyas, Tokoh Pertelevisian Indonesia 